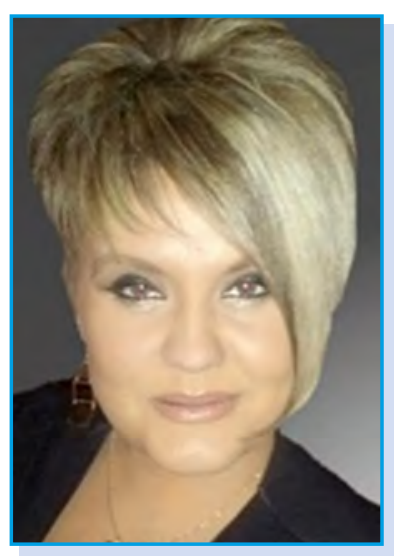

Вікторія Купрієвич - кандидат педагогічних наук, доцент кафедри професійної і вищої освіти Центрального інституту післядипломної освіти ДЗВО «Університет менеджменту освіти» НАПН України, м. Київ, Україна.

Коло наукових інтересів: андрагогіка, самовдосконалення особистості, формування самоосвітньої компетентності керівників закладів професійної освіти в процесі підвищення кваліфікації, світові тенденції розвитку післядипломної освіти.

vik_torik@ukr.net

https://orcid.org/0000-0002-8196-8309

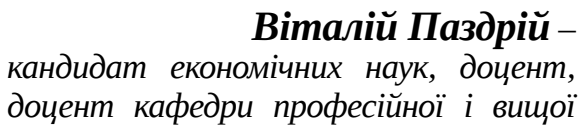
освіти Центрального інституту післядипломної освіти ДЗВО «Університет менеджменту освіти» НАПН Украӥни, м. Київ, Украӥна.

Коло наукових інтересів: освітній простір, простір вищої освіти, освітня політика, розвиток підприємницької компетентності здобувачів освіти та освітнього підприємництва, актуальні проблеми сучасної професійної та вищої освіти.

pazdriy.v@gmail.com

iD https://orcid.org/0000-0001-5713-282X

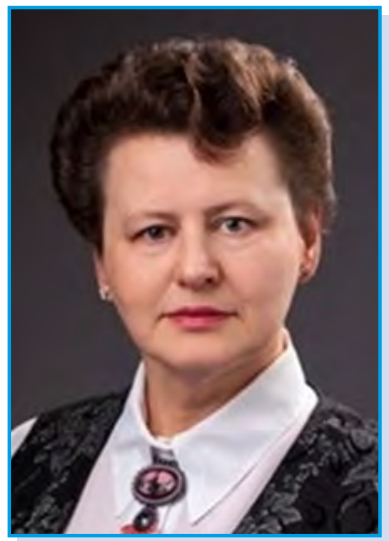

Людмила Антонюк - старший викладач кафедри професійної і вищої освіти Центрального інституту післядипломної освіти ДЗВО «Університет менеджменту освіти» НАПН України, м. Київ, Україна.

Коло наукових інтересів: освіта дорослих, європейські реформи в галузі вищої та післядипломної освіти, двомовна освіта, педагогічні інновації в галузі вищої освіти; педагогіка професійної освіти.

ludmillaa007@ukr.net

https://orcid.org/ 0000-0001-6484-6185

УДК 378.6.046-021.68:37].011.33

https://doi.org/10.32405/2411-1317-2021-4-198-205

\title{
ОСОБЛИВОСТІ ОРГАНІЗАЦІЇ ТА ФОРМИ ПІДВИЩЕННЯ КВАЛІФІКАЦІЇ ПЕДАГОГІЧНИХ ПРАЦІВНИКІВ ЗАКЛАДІВ ПРОФЕСІЙНОÏ (ПРОФЕСІЙНО-ТЕХНІЧНОЇ) ОСВІТИ
}

У статті визначено форми та особливості організації навчання в системі підвищення кваліфікації педагогічних працівників закладів професійної (професійно-технічної) освіти в навчально- 
му середовищі закладу післядипломної освіти. Уточнено контент навчальних програм на основі освітньо-професійної програми підвищення кваліфікації цієї категорії слухачів, визначено сутність основних понять дослідження. Доведено, що процес підвищення кваліфікації педагогічних працівників закладів професійної (професійно-технічної) освіти має конкретизуватися специфікою таких закладів.

Ключові слова: підвищення кваліфікації, заклад післядипломної освіти, педагогічний працівник, розвиток, зміст освіти.

Постановка проблеми. Ефективність змін та перетворень у закладах освіти, зокрема в закладах професійної (професійно-технічної) освіти (далі ЗП(ПТ)О), залежить від наявності професійно підготовлених, компетентних керівних і педагогічних кадрів. Успішні перетворення, реформи та інновації в ЗП(ПТ)О передбачають значну відповідальність керівного та педагогічного складу. Окрім того, успіх реформ у закладах освіти сьогодні значною мірою залежить від рівня професійного розвитку як керівників, так і педагогічних працівників цих установ.

За таких умов доволі актуальним є розв'язання завдань, пов'язаних із динамічним оновленням змісту підвищення кваліфікації педагогічних працівників ЗП(ПТ)О в закладах післядипломної педагогічної освіти. Саме тому реформування освіти, яке здійснюється сьогодні в Україні, кардинально має змінити підходи до змісту і структури післядипломної педагогічної освіти (далі ППО).

Післядипломна освіта $є$ невід'ємним складником освіти дорослих. Вона забезпечує безперервний професійний розвиток фахівців різних галузей відповідно до вимог державної освітньої політики, запитів роботодавців і стейкхолдерів, а також потреб споживачів освітніх послуг (Кремень, 2021, с. 89).

Мережа закладів і установ післядипломної освіти є достатньо розгалуженою. Одним із флагманів післядипломної освіти є ДЗВО «Університет менеджменту освіти» НАПН України. Саме в Центральному інституті післядипломної освіти цього університету підвищують кваліфікацію зокрема і керівні та педагогічні працівники ЗП(ПТ)О.

Аналіз останніх досліджень і публікацій з проблеми. В умовах сьогодення освіта дорослих $€$ одним із головних інструментів успішного протистояння викликам, з якими стикається Європа і наша країна. Грунтовно розглядають проблеми освіти дорослих такі зарубіжні дослідники, як С. Вернер, Т. Грехем, Д. Кемпбел, А. Роджерс, С. Хоул та інші. Окремі аспекти освіти дорослих у сучасній українській освіті досліджували С. Болтівець, В. Даниленко, Р. Дронікова, Б. Матвієнко, Н. Ничкало, Л. Сергеєва, Л. Сігаєва, Т. Сорочан.

Проблему інноваційної спрямованості змісту і технологій системи післядипломної педагогічної освіти досліджували: Т. Алєксєєнко, В. Аніщенко, В. Биков, В. Кремень, В. Олійник, І. Якухно.

Проблеми теорії та практики навчання фахівців у системі підвищення кваліфікації, зокрема післядипломної педагогічної освіти, висвітлені у працях $Є$. Бєлозерцева, Н. Борисової, Т. Браже, Л. Гранюк, В. Демчук, А. Єрмоли, К. Зарипова, М. Красовицького, А. Кузьмінського, Ю. Кулюткіна, В. Маслова, О. Мармази, І. Олександрової, В. Олійника, В. Пуцова, Г. Сущенко, та інших. Автори розглядають як загальнометодологічні, так і технологічні аспекти навчання педагогічних кадрів у системі підвищення кваліфікації.

Як свідчать дослідження науковців, у сучасній системі ППО спостерігається загострення проблеми забезпечення розвитку професійної компетентності педагогів, що виявляється у таких аспектах:

- технократизм, прагматизм і гуманнодефіцитність, відсутність належного матеріального й морального стимулювання педагогічних працівників;

- нормативно-правове впорядкування функціонування системи ППО, інформатизація освітньої діяльності, структура й організація навчання та ін.

3 огляду на вищезазначене у теорії і практиці післядипломної педагогічної освіти простежується тенденція пошуку продуктивних підходів до розв'язання актуальних завдань розвитку післядипломної освіти, створення цілісної системи навчання людини упродовж життя (Кириченко, 2018, с. 63). 
Вивчення наукової літератури дає можливість стверджувати, що вимоги суспільства змушують педагогічних працівників ЗП(ПТ)О постійно набувати нових компетентностей, а навчання на курсах підвищення кваліфікації має створити умови для забезпечення всебічного і гармонійного розвитку особистості, задоволення ії різноманітних освітніх потреб, сприяння самовизначенню і самореалізації та досягненню власних цілей життєдіяльності.

Освітній процес у закладах підвищення кваліфікації має свої особливості зумовлені специфікою навчання дорослих людей з вищою освітою та набутим досвідом педагогічної діяльності. Це актуалізує розроблення нових технологій і методик організації освітнього процесу, які б відповідали сучасним вимогам до його ефективності на основі чіткої стратегії навчання слухачів і об’єктивного оцінювання можливостей закладу (Молчанова, Купрієвич, 2019, с. 79).

У цьому контексті актуалізується проблема вдосконалення освітнього процесу в закладах системи підвищення кваліфікації педагогічних кадрів ЗП(ПТ)О і приведення його у відповідність до сучасних вимог.

Мета статті полягає у визначенні специфіки організації та форм організації навчання в системі підвищення кваліфікації педагогічних працівників закладів професійної (професійнотехнічної) освіти в навчальному середовищі закладу післядипломної педагогічної освіти.

Виклад основного матеріалу. В умовах соціальних трансформацій, які потребують глибинних перетворень у системі професійної (професійно-технічної) освіти, важливого значення набуває підготовка керівних та педагогічних працівників ЗП(ПТ)О, які здатні забезпечити модернізацію і оновлення структури, форм і змісту професійної освіти та підготовку спеціалістів нового формату, що будуть опановувати складні професійні компетентності, різні форми інтеграції професій з оновленим змістом навчання; це сприяє задоволенню освітніх і духовнокультурних потреб усіх суб'єктів освітнього процесу, розвитку їхньої здатності до саморозвитку та навчання упродовж усього життя.

Особливе місце в цьому процесі належить системі ППО, оскільки вона за своїм призначенням фактично забезпечує підвищення кваліфікації фахівців, є інструментом перебудови освітньої галузі і, відповідно, соціальних перетворень на якісно новому рівні. Саме в системі ППО, враховуючи специфіку контингенту слухачів, можливо створити інноваційно-розвивальне середовище, в якому, спираючись на професійний досвід фахівців, ініціювати їхній професійний та особистісний розвиток, сприяти проєктуванню слухачем власної стратегії ефективної професійної діяльності (Сергеєва, Купрієвич, 2020, с. 6).

Визначаються загальні тенденції підвищення кваліфікації педагогічних і керівних кадрів. Серед них: диференціація змісту навчання у відповідності з індивідуальними освітніми потребами, залучення слухачів до визначення змісту їх курсового навчання, застосування інтерактивних методів навчання, діалогізація освітнього процесу, його побудова на основі критичного аналізу практики, розвиток творчої і моральної сфери особистості, спрямування освітнього процесу на навчання у міжкурсовий період, посилення уваги до користування комп’ютерною технікою та сучасними засобами комунікації, стимулювання самоосвіти.

Головна ідея підвищення кваліфікації педагогічних працівників ЗП(ПТ)О полягає в розвитку їх загальних і спеціальних (посадово-функціональних компетентностей) на основі базової освіти, професійного та життєвого досвіду, особистісних інтересів, соціальних запитів і потреб держави щодо ефективного виконання професійних обов'язків керівниками та педагогічними працівниками ЗП(ПТ)О. Підвищення кваліфікації цієї категорії слухачів може відбуватися за очно-дистанційною або очною формою відповідно до Концепції розвитку системи підвищення кваліфікації фахівців у Центральному інституті післядипломної освіти ДЗВО «Університет менеджменту освіти» НАПН України та затверджених диференційованих моделей структури підвищення кваліфікації слухачів.

Згідно з освітньо-професійною програмою підвищення кваліфікації напряму «Педагогічні, науково-педагогічні працівники та керівники закладів освіти» галузі знань: 01 «Освіта» категорії слухачів: «Керівники закладів професійної (професійно-технічної) освіти та науково-методичних 
установ професійної (професійно-технічної) освіти» обсяг одного навчального модуля установлений у межах 30 год. / 1 кред., кількість обов’язкових модулів - 5 (Сергеєва, Купрієвич, 2020).

У цілому обсяг програми підвищення кваліфікації керівників та педагогічних працівників ЗП(ПТ)О за очною моделлю навчання становить 150 год. / 5 кред., за очно-дистанційною (дистанційною) формою навчання - 150 год. / 5 кред.

Кожен модуль має дві складові: нормативну та вибіркову. Це дасть змогу диференціювати навчання слухачів з різною підготовкою та досвідом професійної діяльності, а також зараховувати попереднє неформальне навчання.

Розподіл годин за очною моделлю навчання (150 год. / 5 кред.) з урахуванням аудиторної та самостійної робіт здійснюється відповідно до табл. 1.

Таблиця 1.

Розподіл годин за очною / дистанційною моделлю навчання

(150 год / 5 кред. ЄКТС)

\begin{tabular}{|c|c|c|c|c|c|c|c|}
\hline \multirow[b]{2}{*}{ Модулі } & \multirow[b]{2}{*}{ 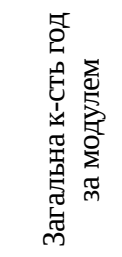 } & \multicolumn{3}{|c|}{ Обсяг аудиторних год. } & \multicolumn{3}{|c|}{ Обсяг самостійної роботи (у год.) } \\
\hline & & 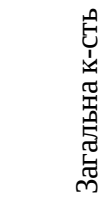 & 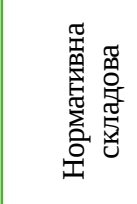 & 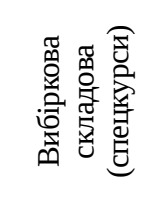 & 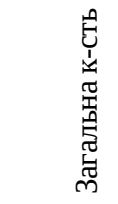 & 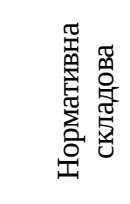 & 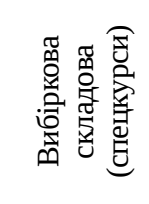 \\
\hline Модуль 1 & 30 & 14 & 10 & 4 & 16 & 8 & 8 \\
\hline Модуль 2 & 30 & 14 & 10 & 4 & 16 & 8 & 8 \\
\hline Модуль 3 & 30* & $16^{*}$ & $12 *$ & $4 *$ & $14^{*}$ & $6^{*}$ & $8 *$ \\
\hline Модуль 4 & 30 & 14 & 10 & 4 & 16 & 8 & 8 \\
\hline \multirow[t]{2}{*}{ Модуль 5} & 30 & 14 & 10 & 4 & 16 & 8 & 8 \\
\hline & 150 & 72 & 52 & 20 & 78 & 38 & 40 \\
\hline
\end{tabular}

* години відводяться на модуль випускової кафедри.

За очно-дистанційною та дистанційною формами навчання (150 год. / 5 кред. ЄКТС) відповідно до табл. 2-4.

Концептуальними для ППО вважаються ідеї стійкого руху до європейського освітнього простору, забезпечення нової якості освіти та професійного розвитку, перетворення навчання упродовж життя на реальність, створення системи методичного супроводу управління на основі інноваційних стратегій тощо. Це вимагає осучаснення програм підвищення кваліфікації та адаптування їх до потреб особистості фахівця, створення умов для його саморозвитку та практичного самовираження.

Післядипломна педагогічна освіта не просто доповнює базову професійну освіту, а й підтримує і вдосконалює керівників та педагогічних працівників ЗП(ПТ)О як фахівців, створює творче середовище для їх самоактуалізації, саморозвитку та самовдосконалення. Нові концептуальні засади підвищення кваліфікації керівників та педагогічних працівників ЗП(ПТ)О базуються на цілому комплексі компетентностей: соціально-психологічних, нормативних, управлінських, інноваційно-дослідницьких, інтелектуальних, науково-методичних, інформаційнокомунікаційних, професійних. Це знаходить своє відображення в оновлених робочих навчальних програмах Центрального інституту післядипломної освіти ДЗВО «Університет менеджменту освіти» НАПН України, які мають модульну структурованість, орієнтовані на індивідуальну і самостійну роботу слухачів курсів підвищення кваліфікації з урахуванням їх особистісних потреб (Купрієвич, 2021, с. 4). 
Таблиця 2.

Розподіл часу за очно-дистанційною та дистанційною формами навчання (150 год. / 5 кред. ЄКТС; 17 тижнів)

\begin{tabular}{|c|c|c|c|c|c|c|c|c|c|c|c|c|}
\hline \multirow[b]{3}{*}{ Модулі } & \multirow{3}{*}{ 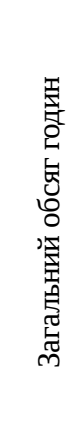 } & \multicolumn{6}{|c|}{ Очні етапи (очний етап) } & \multicolumn{5}{|c|}{ Дистанційний етап } \\
\hline & & \multicolumn{3}{|c|}{$\begin{array}{c}\text { Обсяг } \\
\text { аудиторних } \\
\text { год. }\end{array}$} & \multicolumn{3}{|c|}{$\begin{array}{c}\text { Обсяг } \\
\text { самостійної роботи } \\
\text { (у год.) }\end{array}$} & \multirow{2}{*}{ 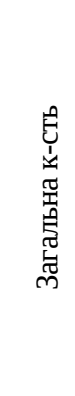 } & \multicolumn{2}{|c|}{$\begin{array}{c}\text { Обсяг } \\
\text { аудиторних } \\
\text { год. (дистан- } \\
\text { ційно) }\end{array}$} & \multicolumn{2}{|c|}{$\begin{array}{c}\text { Обсяг } \\
\text { самостійної } \\
\text { роботи }\end{array}$} \\
\hline & & 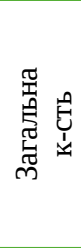 & 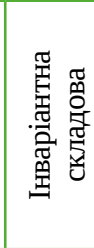 & 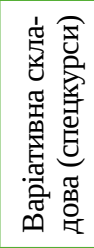 & 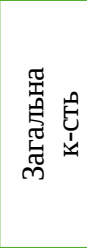 & 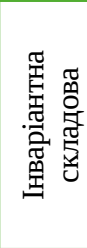 & 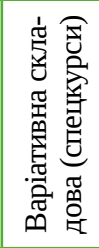 & & 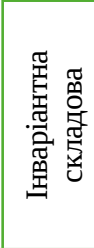 & 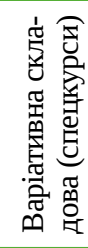 & 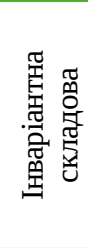 & 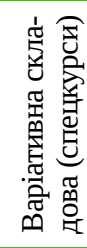 \\
\hline Модуль 1 & 30 & 10 & 6 & 4 & $\mathbf{0}$ & 0 & 0 & 20 & 0 & 4 & 0 & 16 \\
\hline Модуль 2 & 30 & 8 & 8 & 0 & 1 & 0 & 1 & 21 & 2 & 4 & 7 & 8 \\
\hline Модуль 3 & 30 & $14^{*}$ & $10^{*}$ & $4^{*}$ & $1 *$ & $1 *$ & 0 & $15^{*}$ & $6^{*}$ & 0 & $1^{*}$ & $8^{*}$ \\
\hline Модуль 4 & 30 & 8 & 8 & 0 & $\mathbf{0}$ & 0 & 0 & 22 & 0 & 4 & 10 & 8 \\
\hline \multirow{2}{*}{ Модуль 5} & 30 & 8 & 8 & 0 & $\mathbf{0}$ & 0 & 0 & 22 & 4 & 4 & 6 & 8 \\
\hline & 150 & 48 & 40 & 8 & 2 & 1 & 1 & 100 & 12 & 16 & 24 & 48 \\
\hline
\end{tabular}

* години відводяться на модуль випускової кафедри

Таблиця 3.

Розподіл часу за очно-дистанційною та дистанційною формами навчання

(150 год. / 5 кред. ЄКТС) (очні етапи 5 дн. + 5 дн.; 12 тижнів)

\begin{tabular}{|c|c|c|c|c|c|c|c|c|c|c|c|c|}
\hline \multirow[b]{3}{*}{ Модулі } & \multirow{3}{*}{ 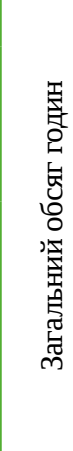 } & \multicolumn{6}{|c|}{ Очні етапи } & \multicolumn{5}{|c|}{ Дистанційний етап } \\
\hline & & \multicolumn{3}{|c|}{$\begin{array}{c}\text { Обсяг } \\
\text { аудиторних год. }\end{array}$} & \multicolumn{3}{|c|}{$\begin{array}{c}\text { Обсяг } \\
\text { самостійної } \\
\text { роботи (у год.) }\end{array}$} & \multirow{2}{*}{ 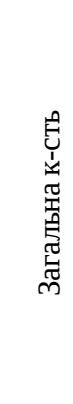 } & \multicolumn{2}{|c|}{$\begin{array}{c}\text { Обсяг } \\
\text { аудиторних } \\
\text { год. (дистан- } \\
\text { ційно) }\end{array}$} & \multicolumn{2}{|c|}{$\begin{array}{c}\text { Обсяг } \\
\text { самостійної } \\
\text { роботи }\end{array}$} \\
\hline & & 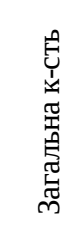 & 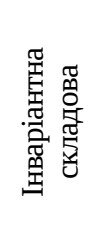 & 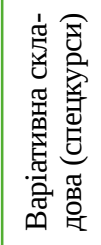 & 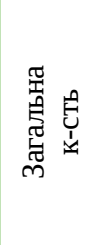 & 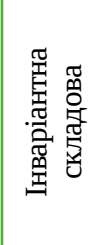 & 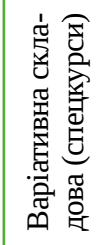 & & 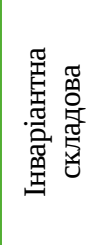 & 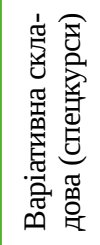 & 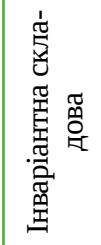 & 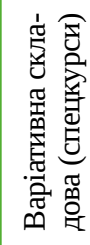 \\
\hline Модуль 1 & 30 & 12 & 8 & 4 & 6 & 2 & 4 & 12 & 0 & 4 & 0 & 8 \\
\hline Модуль 2 & 30 & 10 & 10 & 0 & 6 & 6 & 0 & 14 & 0 & 4 & 2 & 8 \\
\hline Модуль 3 & 30 & $18 *$ & $14 *$ & $4 *$ & $6 *$ & $0 *$ & $6 *$ & 6* & $4 *$ & $0 *$ & $2 *$ & $0 *$ \\
\hline Модуль 4 & 30 & 10 & 10 & 0 & 6 & 6 & 0 & 14 & 0 & 4 & 2 & 8 \\
\hline \multirow[t]{2}{*}{ Модуль 5} & 30 & 10 & 10 & 0 & 6 & 6 & 0 & 14 & 0 & 4 & 2 & 8 \\
\hline & 150 & 60 & 52 & 8 & 30 & 20 & 10 & 60 & 4 & 16 & 8 & 32 \\
\hline
\end{tabular}

* години відводяться на модуль випускової кафедри 
Таблиця 4.

Розподіл часу за очно-дистанційною та дистанційною формами навчання (150 год. / 5 кред. ЄКТС) (очні етапи 5 дн. + 5 дн.; 17 тижнів)

\begin{tabular}{|c|c|c|c|c|c|c|c|c|c|c|c|c|}
\hline \multirow[b]{3}{*}{ Модулі } & \multirow{3}{*}{ 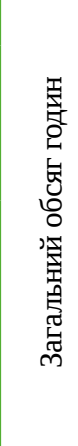 } & \multicolumn{6}{|c|}{ Очні етапи } & \multicolumn{5}{|c|}{ Дистанційний етап } \\
\hline & & \multicolumn{3}{|c|}{$\begin{array}{c}\text { Обсяг } \\
\text { аудиторних } \\
\text { год. }\end{array}$} & \multicolumn{3}{|c|}{$\begin{array}{c}\text { Обсяг } \\
\text { самостійної } \\
\text { роботи (у год.) }\end{array}$} & \multirow{2}{*}{ 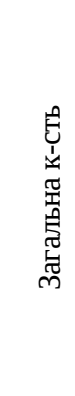 } & \multicolumn{2}{|c|}{$\begin{array}{c}\text { Обсяг } \\
\text { аудиторних } \\
\text { год.(дистан- } \\
\text { ційно) }\end{array}$} & \multicolumn{2}{|c|}{$\begin{array}{c}\text { Обсяг } \\
\text { самостійної } \\
\text { роботи }\end{array}$} \\
\hline & & 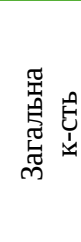 & 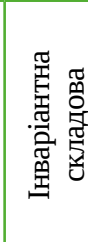 & 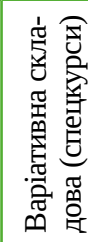 & 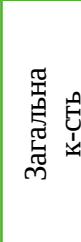 & 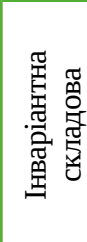 & 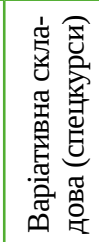 & & 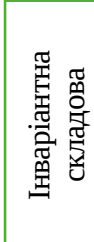 & 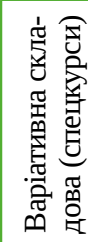 & 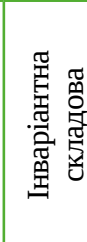 & 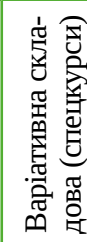 \\
\hline Модуль 1 & 30 & 12 & 8 & 4 & $\mathbf{0}$ & 0 & 0 & 18 & 0 & 4 & 0 & 14 \\
\hline Модуль 2 & 30 & 10 & 10 & 0 & 1 & 1 & 0 & 19 & 2 & 4 & 5 & 8 \\
\hline Модуль 3 & 30 & $16^{*}$ & $12^{*}$ & $4^{*}$ & $1^{*}$ & $0 *$ & $1 *$ & $13^{*}$ & 6* & 0 & $1 *$ & 6* \\
\hline Модуль 4 & 30 & 12 & 12 & 0 & $\mathbf{0}$ & 0 & 0 & 18 & 0 & 4 & 6 & 8 \\
\hline \multirow[t]{2}{*}{ Модуль 5} & 30 & 10 & 10 & 0 & $\mathbf{0}$ & 0 & 0 & 20 & 4 & 4 & 4 & 8 \\
\hline & 150 & 60 & 52 & 8 & 2 & 1 & 1 & 88 & 12 & 16 & 16 & 44 \\
\hline
\end{tabular}

* години відводяться на модуль випускової кафедри

Ціннісними пріоритетами процесу підвищення кваліфікації стають: орієнтація навчання на психологічну перебудову особистості фахівця, його психологічних установок; розвиток професійно значущих якостей особистості спеціаліста; формування у нього стійкої мотивації до професійного самовдосконалення та саморозвитку.

Зміст навчання в системі підвищення кваліфікації педагогічних кадрів ЗП(ПТ)О - це зміст прогресивних змін, властивостей та якостей особистості, які відбуваються в період після здобуття фахівцем вищої освіти й до кінця його професійної педагогічної кар’єри.

Сьогодні вкрай важливо, грунтуючись на принципах відкритої освіти, організувати безперервний процес розвитку інформаційно-комунікаційної, професійної та психологічної компетентностей особистості в системі удосконалення педагогічних кадрів. Така освіта суттєво відрізняється від традиційної, вона є освітньою системою більш високого рівня і більшою мірою відповідає цілям і задачам інформаційного суспільства. Відкрита освіта становить собою гнучку систему отримання знань, доступну будь-кому без аналізу його освітнього цензу та регламентації періодичності й тривалості навчання, що розвивається на основі формалізації знань, їх передачі і контролю з використанням інформаційних і педагогічних технологій (Василюк, 2017, с. 96).

Враховуючи вищевикладене приходимо до висновку, що організовувати підвищення кваліфікації керівних та педагогічних кадрів ЗП(ПТ)О доцільно таким чином, щоб:

- навчання мало, насамперед, практичну спрямованість;

- використовувалися різні форми роботи зі слухачами, залежно від попереднього досвіду їх професійної діяльності;

- була здатність вчасно виявляти і педагогічно виважено реагувати на існуючі та перспективні потреби педагогічних працівників ЗП(ПТ)О;

- слухачі курсів підвищення кваліфікації могли критично оцінювати запропоновані в межах курсів підвищення кваліфікації інновації та брати безпосередню участь у їх апробації, розвитку та інтеграції; 
- існувала гнучкість у відборі змісту навчання;

- у слухачів була можливість вибору часу і темпів навчання.

При цьому зміст навчання повинен формуватися відповідно до функцій та завдань, покладених на педагогічних працівників закладів професійної (професійно-технічної) освіти.

Висновки та перспективи подальших досліджень. Ефективність підвищення кваліфікації й усієї системи ППО залежить від злагодженої роботи всіх ланок цієї системи, від комплексного підходу до їх вдосконалення на основі розвитку науково-дослідної, навчально-методичної та викладацької діяльності.

Загалом можна відзначити, що організація безперервного процесу підвищення кваліфікації педагогічних працівників ЗП(ПТ)О є актуальною проблемою. Ї̈̈ вирішення - в удосконаленні чинної системи і масштабному використанні наукових і методологічних напрацювань у галузі навчання дорослих.

Нова філософія ППО зумовлює необхідність її нової організації на засадах упровадження ідей відкритої освіти, які дозволяють гідно зустріти виклики інформаційного суспільства й відреагувати на трансформацію освітнього запиту щодо підготовки фахівців освітньої галузі високої якості, вмотивованих на ефективну діяльність в умовах динамічних змін за різних, навіть несприятливих, умов. Ці ідеї спонукають до суттєвого переформатування післядипломної педагогічної освіти, переходу до освітніх систем відкритого типу, що функціонують на засадах застосування мережевих технологій, децентралізації та демократизації освіти, відкритого формування структури і обсягів освітньої та професійної підготовки фахівців.

\section{Використані джерела}

[1] Кириченко, О.М., Сергеєва, Л.М. (ред). (2018). Відкрита освіта: інноваційні технології та менеджмент: колективна монографія. Київ: Інтерсервіс.

[2] Купрієвич, В.О. (2021). Сучасні вимоги до змісту післядипломної освіти керівників закладів професійної (професійно-технічної) освіти: Професійні компетенції сучасного керівника як фактор розвитку освітньої сфери: IV Міжн. наук.-практ. семінар / М-во освіти Респ. Білорусь. ГУО «Академия последипломного образования». Минск. 274-280. URL: https://ib.iitta.gov.ua/725925/

[3] Молчанова, А.О., Купрієвич, В.О. (2019). Підвищення кваліфікації як фактор компетентнісного зростання керівних кадрів професійної освіти. Вісник післядипломної освіти: зб. наук. праць / НАПН України ДЗВО «УНт менедж. освіти». Серія «Педагогічні науки». 9(38). 78-98. https://doi.org/10.32405/2218-7650-9(38)-78-98

[4] Кремень, В.Г. (ред). (2021). Національна доповідь про стан і перспективи розвитку освіти в Україні: монографія. Київ: КОНВІ ПРІНТ. https://doi.org/10.37472/NAES-2021-uа

[5] Василюк, А., Стоговський А. (ред.). (2017). Освіта дорослих у перспективі змін: інновації, технології, прогнози: колективна. Ніжин: Видавець ПП Лисенко М.М.

[6] Чернишова, Є. Р., Гузій, Н. В., Ляхоцький, В. П. (2014). Підготовка науково-педагогічних кадрів у системі післядипломної педагогічної освіти: зміст, організаційні форми, технології. Київ: ДВНЗ «УН-т менеджменту освіти» НАПН України.

[7] Сергеєва, Л.М., Купрієвич, В.О. (2020). Освітньо-професійна програма підвищення кваліфікації напряму «Педагогічні, науково-педагогічні працівники та керівники закладів освіти» галузі знань: 01 «Освіта» категорії слухачів: «Керівники закладів професійної (професійно-технічної) освіти та науково-методичних установ професійної (професійно-технічної) освіти». Київ: ДЗВО «Ун-т менедж. освіти». URL: https://lib.iitta.gov.ua/724670/

[8] Зінченко, В. (ред). (2020). Стратегії вищої освіти в умовах інтернаціоналізації для стійкого розвитку суспільства: монографія. Київ: Інститут вищої освіти НАПН України.

\section{References}

[1] Kyrychenko, O.M., Serheieva, L.M. (red). (2018). Vidkryta osvita: innovatsiini tekhnolohii ta menedzhment: kolektyvna monohrafiia. Kyiv: Interservis. (in Ukrainian).

[2] Kupriievych, V.O. (2021). Suchasni vymohy do zmistu pisliadyplomnoi osvity kerivnykiv zakladiv profesiinoi (profesiino-tekhnichnoi) osvity: Profesiini kompetentsii suchasnoho kerivnyka yak faktor rozvytku osvitnoi 
sfery: IV Mizhn. nauk.-prakt. seminar / M-vo osvity Resp. Bilorus. HUO «Akademyia posledyplomnoho obrazovanyia». Mynsk. 274-280. URL: https://lib.iitta.gov.ua/725925/ (in Ukrainian).

[3] Molchanova, A.O., Kupriievych, V.O. (2019). Pidvyshchennia kvalifikatsii yak faktor kompetentnisnoho zrostannia kerivnykh kadriv profesiinoi osvity. Visnyk pisliadyplomnoi osvity: zb. nauk. prats / NAPN Ukrainy DZVO «Un-t menedzh. osvity». Seriia «Pedahohichni nauky». 9(38). 78-98. https://doi.org/10.32405/22187650-9(38)-78-98 (in Ukrainian).

[4] Kremen, V.H. (red). (2021). Natsionalna dopovid pro stan i perspektyvy rozvytku osvity v Ukraini: monohrafiia. Kyiv: KONVI PRINT. https://doi.org/10.37472/NAES-2021-ua (in Ukrainian).

[5] Vasyliuk, A., Stohovskyi A. (red.). (2017). Osvita doroslykh u perspektyvi zmin: innovatsii, tekhnolohii, prohnozy: kolektyvna. Nizhyn: Vydavets PP Lysenko M.M. (in Ukrainian).

[6] Chernyshova, Ye. R., Huzii, N. V., Liakhotskyi, V. P. (2014). Pidhotovka naukovo-pedahohichnykh kadriv u systemi pisliadyplomnoi pedahohichnoi osvity: zmist, orhanizatsiini formy, tekhnolohii. Kyiv: DVNZ «Un-t menedzhmentu osvity» NAPN Ukrainy. (in Ukrainian).

[7] Serheieva, L.M., Kupriievych, V.O. (2020). Osvitno-profesiina prohrama pidvyshchennia kvalifikatsii napriamu «Pedahohichni, naukovo-pedahohichni pratsivnyky ta kerivnyky zakladiv osvity» haluzi znan: 01 «Osvita» katehorii slukhachiv: «Kerivnyky zakladiv profesiinoi (profesiino-tekhnichnoi) osvity ta naukovometodychnykh ustanov profesiinoi (profesiino-tekhnichnoi) osvity». Kyiv: DZVO «Un-t menedzh. osvity». URL: https://ib.iitta.gov.ua/724670/ (in Ukrainian).

[8] Zinchenko, V. (red). (2020). Stratehii vyshchoi osvity v umovakh internatsionalizatsii dlia stiikoho rozvytku suspilstva: monohrafiia. Kyiv: Instytut vyshchoi osvity NAPN Ukrainy. (in Ukrainian).

Viktoriya Kupriyevych, Candidate of Pedagogical Sciences, Associate Professor of the Department of Professional and Higher Education, University of Educational Management, Kyiv, Ukraine.

Vitalii Pazdrii, Candidate of Economic Sciences, Associate Professor, Associate Professor of the Department of Professional and Higher Education, University of Educational Management, Kyiv, Ukraine.

Liudmyla Antoniuk, Senior Lecturer of the Department of Professional and Higher Education, University of Educational Management, Kyiv, Ukraine.

\section{FEATURES OF THE ORGANIZATION AND FORMS OF PROFESSIONAL DEVELOPMENT OF TEACHERS OF PROFESSIONAL (VOCATIONAL) EDUCATION INSTITUTIONS}

The article defines the forms and features of the organization of professional development in the system of advanced training of teachers of professional (vocational) education institutions in the educational environment of the institution of postgraduate education. Postgraduate pedagogical education by its purpose actually provides advanced training of specialists, is a tool for restructuring the educational sector and, accordingly, social transformations at a qualitatively new level. It is possible to create an innovative and developmental environment in the system of postgraduate pedagogical education in which, taking into account the specifics of the contingent of listeners, you can initiate their professional and personal development, help listeners design their own strategy of effective professional activity, based on the professional experience of specialists. The article also specifies the content of educational programs based on the educational-professional advanced training program of this category of listeners, defines the essence of the basic concepts of the research. The general tendencies of professional development of pedagogical and managerial staff are determined. In this context, the problem of improving the educational process in the institutions of the system of advanced training of teachers of professional (vocational) education institutions and bringing it to the level of modern requirements is relevant. The purpose of the article is to determine the specifics of the organization and forms of training in the system of advanced training of teachers of professional (vocational) education in the educational environment of the institution of postgraduate pedagogical education. It is proved that the process of professional development of teaching staff of institutions of professional (vocational) education should be concretized by the specifics of these institutions.

Keywords: advanced training, postgraduate education, teacher, development, content of education. 